\title{
Refugee Women as a Particular Social Group: A Reconsideration
}

\author{
Victoria Foote
}

\section{Introduction}

The majority of the world's 23 million refugees (Darton 1994, A1) are women and their dependants. Most refugee claimants in Canada, however, are men. Of the 30,000 refugee claimants who arrived in Canada in 1993, less than one-third were female (see Ramirez in this issue). There are several reasons for this discrepancy. Men, unencumbered by the care of children and the elderly, are more mobile than women. They often have greater financial resources at their disposal and are less vulnerable travelling alone than are women. In addition, it is often more culturally acceptable for men to travel on their own. Finally, it is more difficult for women to meet the legal criteria for obtaining refugee status than it is for men.

The 1951 United Nations Convention Relating to the Status of Refugees defines a refugee in Article $1(A)(2)$ as a person who, owing to well-founded fear of being persecuted for reasons of race, religion, nationality, membership in a particular social group, or political opinion is outside the country of his [her] nationality and is unable or, owing to such fear, unwilling to avail himself [herself] of the protection of that country.

The gender-neutral language of the Convention definition is deceptive. Hidden in the neutrality is an understanding of persecution, and the grounds upon which it is legally based, that has been formulated by a distinctly male perception of what constitutes a legitimate fear of persecution. Because gender is absent as an enumerated basis for fear of persecution, the Convention definition fails to acknowledge that in some-perhaps

Victoria Foote is a M.A. student, Faculty of Environmental Studies, York University, and a graduate researcher at $C R S$. most-countries, women face persecution specifically because they are women (Castel 1992).

At both the national and the international levels, several policy documents and accompanying statements of intent have been issued over the past decade with the express purpose of ameliorating this situation. The Canadian Women at Risk (AWR) program, implemented in 1988, is one such policy. The Guidelines on Woman Refugee Claimants Fearing Gender-Related Persecution, issued in March 1993 by Chairperson Nurjehan Mawani of the Immigration and Refugee Board (IRB) are another. The Guidelines were produced out of concern over the omission of gender-specific persecution in the Convention definition. The AWR program, implemented several years before the publication of the Guidelines, was designed to "assist refugee advocated in the Guidelines for manipulating the Convention definition so that it may better meet the needs of refugee women. Specifically, it is important to consider the ramifications of assigning women refugees to a category that implicitly if not explicitly suggests that gender-specific persecution of women refugees is an aberration of more conventionally acceptable forms of persecution.

\section{Background to the Release of the Guidelines}

According to Chairperson Mawani $(1993,7)$, the Guidelines were the inevitable outcome of previous statements of policy issued at the international level, usually via the United Nations High Commissioner for Refugees (UNHCR), concerning the omission of gender in the Convention definition as grounds for persecution. Others, such women who are particularly at risk, when this is deemed to be the only viable durable solution for them" (UNHCR memorandum 77/88). Today, only three countries have a Women at Risk program: Canada, Australia, and New Zealand. The United States is currently beginning a pilot project. The Guidelines, in turn, are unique to Canada.

The purpose of this paper is to examine and analyze the argument made by the IRB in the Guidelines, that women refugee claimants can and should base their claims-under the appropriate circumstances-on the grounds of belonging to a particular social group as outlined in the Convention definition. I am especially concerned with the line of reasoning as refugee lawyer Audrey Macklin (1993, 1; 1995) suggest that the public outcry over the well-publicized rejection of several female applicants who had based their claims on gender persecution led to the issuance of the Guidelines. To some extent, both are correct. Recommendations had been made at the international level to accommodate gender-specific persecution through a broadened interpretation of the Convention definition. This, in turn, encouraged the establishment at the IRB of the Working Group on Women Refugee Claimants in 1990 , whose mandate was to address the specific problems faced by women refugee claimants (see Ramirez in this issue). In addition, the outcry over the dismissed claims may well have 
served to give the IRB a final push to produce a document such as the Guidelines.

In 1984, the European Parliament adopted a resolution encouraging states to recognize as refugees women who face persecution because they transgressed the social mores of their communities (Stairs and Pope 1990). Applicants basing their claims on such a transgression, the European Parliament suggested, could be subsumed under the Convention definition category known as "membership in a particular social group." This was the first time such claims were recognized (Goldberg 1993). Shortly thereafter, in 1985, the Executive Committee of UNHCR endorsed Conclusion No. 39, "which recognized that states are free to adopt an interpretation of social group that would include women asylum seekers 'who face harsh or inhuman treatment due to their having transgressed the social mores of the society in which they live' " (Stairs and Pope 1990, 167). Then, in 1988, the International Consultation on Refugee Women in Geneva-echoing the earlier actions of the European Parliament-called upon all states that are signatories of the 1967 Protocol to consider women persecuted on the basis of gender as part of a "particular social group." Finally, in 1991, the UNHCR adopted the "Guidelines on the Protection of Refugee Women," which also encouraged states to recognize claims made by women on the grounds of gender-specific persecution. The UNHCR Guidelines recommended that such persecution could fall under the "political opinion" or, in some cases, the "religious" category specified by the Convention definition (Goldberg 1993).

These policy statements and accompanying documents, with the exception of the 1991 UNHCR Guidelines, reiterate the notion that women refugees can be understood as constituting a particular social group. By the time the Guidelines were released in March 1993, it was hardly surprising that rather than advocate that "gender" be added as legitimate grounds for bas- ing a refugee claim, the IRB recommended instead that, barring other options already stated explicitly in the Convention definition, women refugee claimants should declare themselves as belonging to a "particular social group" in order to justify their refugee status. The IRB Guidelines thus follow the precedent set during the 1980 s by the European Parliament, the UNHCR, and the 1988 International Consultation on Refugee Women.

\section{Refugee Women as a Particular Social Group}

The UN refugee definition acknowledges persecution based only on publicly apparent enumerated grounds that often do not reflect the private reality of women's lives. Moreover, the definition requires a state connection to the persecution feared (Stairs and Pope 1990). Traditionally, argues Goldberg (1993), human rights doctrines-which include the Convention definition-have focused on the human rights of men. The "objective standard" of what constitutes a human rights violation refers to the male experience as the norm. Because this male

cause of their sex. This is not random violence; the risk factor is being female."

The express purpose of the Guidelines is to compensate for the Convention definition's omission of genderrelated persecution. The opening statement of the Guidelines declares gender-related persecution as a "form of persecution which can and should be assessed by the Refugee Division panel hearing the claim.... The central issue is ... the need to determine the linkage between gender, the feared persecution and one or more of the definition grounds" (Guidelines 1993, 1). In reference to the Guidelines, Chairperson Mawani writes, "the IRB is seeking to apply the notion of persecution in a way that reflects the reality of persecution against women, an aim not fully envisaged at the time of the adoption of the Convention" $(1993,8)$.

There is increasing international support, the Guidelines $(1993,5)$ point out, "for the application of the particular social group ground to the claims of women who allege a fear of persecution solely by reason of their gender." The Guidelines go on to outline the cir-

\section{The IRB Guidelines thus follow the precedent set during the 1980s by the European Parliament, the UNHCR, and the 1988 International Consultation on Refugee Women.}

point of view has determined the measurement of aberrant behavior, gender-based violations are not accounted for (Ibid.). Examples of gender-based human rights violations are rape (which has not historically been considered grounds for claiming refugee status), dowry deaths (for brides who bring too few resources to their marriage), sati (practice of a widow immolating herself on her husband's funeral pyre), forced marriages, compulsory abortion or sterilization, female infanticide, genital mutilation, and domestic violence, all of which "represent female specific forms of persecution for which there are few male corollaries" (Guidelines 1993, 7). As Heise writes in the Guidelines, "women are targets of violence be- cumstances under which membership in a particular social group would be the appropriate course for a claim to take. Four factors must be considered when establishing a well-founded fear of persecution by reason of membership in a social group: first, the possibility that a particular social group might consist of a large population is irrelevant; second, that the particular social group suffers, or fears suffering, severe discrimination such that the group can be distinguished from the rest of the general population, or from other women (emphasis added); third, that the particular group can be identified by their exposure to violence-including domestic violence-and further, that their exposure as women is due, in part or entirely, to the fact 
that they are unprotected; and fourth, that gender can be shown to be the sole reason for feared harm, that the harm is persecutory in nature, and that the claimant has reason to fear a continuation of that harm were she to return to her country of origin in lieu of adequate state protection.

The following example demonstrates the application of the social group category in accordance with the dictates of the Guidelines. "Dularie," a woman from Trinidad, fled her homeland for Canada after having been repeatedly beaten for a number of years by her husband. Despite her pleas, the state authorities of Trinidad refused to intervene. Using the particular social group category, the grounds for persecution, theoretically, could be "Trinidadian women" or "Trinidadian women with male partners" thereby justifying "Dularie's" claim for refugee status (Macklin 1993, 17).

In other words, in instances where one's gender appears to be directly related to some form of persecution, such as sexual abuse, genital mutilation, forced abortion, or the practice of "sati," one should claim that one belongs to a particular social group. In this way, women who have experienced, or fear they will experience, any form of gender-specific persecution may be recognized as legitimate refugee claimants.

According to the Guidelines, basing a refugee claim on the ground of particular social group is not necessarily the best option. A preferable course of action might be to match a claim with the other four grounds for persecution, i.e. race, nationality, religion, or political opinion. For example, a Saudi Arabian woman, "Nada," was subjected to severe harassment for refusing to wear a veil (Macklin 1993, 1). According to the Guidelines, "[a] woman who in an Islamic society ... chooses not to subscribe to or follow the precepts of a state religion may be at risk of persecution for reasons of religion. In the context of the Convention refugee definition, the notion of religion may encompass... the freedom ... not to hold a particular belief system and the free- dom ... not to practise a prescribed religion" $(1993,4)$. "Nada," then, could base her claim to refugee status on religious grounds.

\section{Critique of Women Refugee Claims Based on the Ground of Particular Social Group}

While Goldberg (1993) and, in a qualified way, Macklin (1993; 1995) argue that basing a refugee claim on the grounds of belonging to a particular social group is a poor substitute for what is clearly an instance of genderbased persecution, others (Stairs and Pope 1990) argue that all women should be recognized as constituting a particular social group. On this view, women form a social group because they share certain immutable characteristics and because they are frequently treated differently from men. tic abuse. Had the authors considered this possibility, Macklin suggests, the boundaries between groups of women would become increasingly blurred. In the end, one would probably concede that women, as a whole, could be considered as constituting a particular social group.

At this juncture, Goldberg expresses her disappointment that "gender" was not simply added to the Convention definition of a refugee as a sixth ground for basing a fear of persecution. A new category, she argues, would more fully recognize women who fear or experience gender-specific persecution (1993, 302). Macklin (1993, $29 ; 1995)$ writes that "the feature of the Guidelines which is most vexing from a feminist perspective is the failure of the Government to simply add gender to the list of grounds of persecution

\section{The implication is that women refugees, by virtue of being female, are perennial victims and therefore belong to a particular social group; women are thus put in the uncomfortable position of having their biological characteristics determine their helplessness and subsequent legal status.}

Women are also easily identifiable as a group. A combination of biological and social characteristics, then, renders women a particular social group within the meaning of the Convention definition. Castel adds that women, in general, could be understood as forming a particular social group by virtue of their lack of power within most societies. Women may be classified as belonging to the group of "the disempowered relative to men who, as a group, occupy a privileged position in society" (Castel 1992, 52).

The Guidelines advise restricting the size of a social group so that it may be delineated from the rest of the population or from other women. It is not entirely clear why the Guidelines have stressed this. Macklin (1993; 1995) cynically speculates that those who authored the Guidelines did so on the assumption that Canada would never qualify as a state that did not adequately protect women from domes- rather than opting for a re-interpretation of existing categories." That this course of action has not been taken, claims Macklin (1993), implies that women refugee problems are a subtle variation of men's. Forced abortion, forced pregnancy, or forced clitoridectomy have no parallel in male experience. "Not naming it ... trivializes gender oppression as less damaging than race or religious persecution, and perpetuates the invisibility of its victims" (Macklin 1993, 30). Adds Goldberg, "[a]ll forms of gender-based persecution of women should be recognized by refugee laws. It is essential to a humane asylum policy" (1993, 302).

Macklin qualifies her reaction, however, by pointing to the Guidelines suggestion that opposition to institutionalized discrimination may constitute the expression of "political opinion." If this is the case, then a range of possibilities open up to women refu- 
gee claimants, allowing them to base their claims on the ground of political opinion. According to Macklin (1993, $32 ; 1995)$, "naming women's rejection of subordinate status as a political opinion strikes me as profoundly feminist, if indeed we believe that 'the personal is political' and that patriarchy is a system of power, not biology. So in the end I am not persuaded that employing the category of 'political opinion' is unambiguously inferior to adding the category of gender to the list."

Having established the desirability of basing a claim on the ground of political opinion, Macklin returns to the notion of "particular social group." Women, she observes, are not the only ones left out of the Convention definition of a refugee. For example, persons with disabilities may also be persecuted: "[t]he risk of listing gender as a separate category is that it will give [IRB] Members an excuse to reject people persecuted for reasons of disability by arguing that if the legislator had intended to include disability as a ground of persecution, it would have said so explicitly as it did with gender" (Macklin 1993, 33; 1995). Hence the appeal, for Macklin, of women refugees basing a claim on the ground of particular social group-a very different argument from that of the Guidelines or Stairs and Pope (1990), yet drawing the same conclusions.

I find Macklin's argument in favour of resorting to "particular social group" in claims of gender-based persecution less than persuasive. First, she leaves herself open to her own criticism of "masking" gender persecution with "some other label" (1993, 30; 1995). Second, invoking a particular ground for persecution does not preclude the recognition of other grounds as well. Invoking gender as a ground for persecution does not mean that other forms of persecution do not therefore exist any more than the invoking of, say, religion, as a ground for persecution necessarily implies that race is not, therefore, also a source of persecution. Third, Macklin seems to suggest that persecution is not ac- knowledged as such when aimed at someone who is disabled. Because Macklin does not refer to any examples of such cases, I remain sceptical of the pervasiveness of this problem. On the other hand, examples of women suffering unrecognized forms of persecution, such as rape, abound. Hence the need for the Guidelines in the first place.

Ibelieve it is more likely that women will be equated with "particular social group" in a broadened interpretation of the Convention definition, than that gender will be incorporated into the UN definition of a refugee as a sixth ground for basing a fear of persecution. As mentioned above, the Guidelines specify that, for women refugee claimants to accurately base a fear of persecution on the grounds of belonging to a particular social group, that group should suffer, or fear suffering, severe discrimination such that the group can be distinguished from the rest of the general population, or from other women. The word "or" suggests that, should the group be indistinguishable from other women-in the manner, for example, described by Castel in which women, in general, can be thought of as "disempowered relative to men"- - an argument could still be made justifying the use of particular social group as a legitimate basis for a refugee claim concerning gender-specific persecution.

The "particular" group classification strongly implies that women be categorized and sub-categorized in a manner suggesting that refugee women, despite their majority status among the global refugee population, are an aberration from the norm, as Macklin initially suggests. The implication is that women refugees, by virtue of being female, are perennial victims and therefore belong to a particular social group; women are thus put in the uncomfortable position of having their biological characteristics determine their helplessness and subsequent legal status.

In addition, the classification of women as a "social" group is deeply problematic. Phelan $(1989,57)$ claims that one cannot speak of Women as a specific social entity. To do so is to ignore class and cultural differences. To suggest, as Castel (1992) and Stairs and Pope (1990) do, that women in general may constitute a particular social group reveals a certain cultural image or stereotype that is affixed in our society to a specific arrangement of anatomical features. Feminism, cautions Butler (1990), sometimes entails an urgency to establish a universal status for patriarchy, what Butler $(1990,3)$ calls a "fictive universality of the structure of domination, held to produce women's common subjugated experience." It is this professed "common subjugated experience" that permits, at least in part, the categorization of women as a social group. However, as Butler points out, the political task for feminism is not to refuse representational politics-which, for the purposes of this paper, I think of in reference to the representation of women as a social group for the sake of the political process of refugee determination-since "juridical structures of language and politics constitute the contemporary field of power" $(1990,5)$. Butler suggests that, instead, one may posit a critique of the categories of identity that "contemporary juridical structures engender, naturalize, and immobilize" $(1990,5)$. This is precisely where Castel (1992), Stairs and Pope (1990), and even Macklin (1993) fall short when they, each in her own particular way, group women together as a single social entity either epistemologically (Castel) or legally (Stairs and Pope; Macklin; the Guidelines).

So, although they may be labelled as a "particular social group," women are, in fact, no such thing. The label is affixed in order to steer women through a system which, in part because of the very methodology advocated by the Guidelines, remains profoundly masculinist in outlook. As long as this is the case, claims put forward by women refugees in response to gender-specific persecution will continue to be regarded as something derivative from the norm and, assuming that one's biology dictates one's 
social status for the sake of the legal system, women will continue to be beholden to their biological functions in order either to acquire or to maintain legal legitimacy. One can conclude, therefore, that the Guidelines accept the masculinist framework entrenched within the Convention refugee definition. Consequently, getting some refugee women claimants through the refugee determination process will depend heavily upon the individuals interpreting the definition.

Nor is the ground of political opinion, as suggested by Macklin, and the 1991 UNHCR Guidelines, a happy alternative. Although I find arguments in favour of political opinion as grounds for persecution less compromising than those for particular social group, there are still some difficulties in describing gender-specific persecution in this manner. Macklin's use of the term "political" is sufficiently broad as to risk rendering all other grounds of persecution superfluous. Because she refers to patriarchy as a system of power $(1993,32 ; 1995)$, there appears to be a connection between the use of the word "political" and an understanding of power relations, in this instance between genders. All refugees, however, suffer from a power imbalance. This state of being is not peculiar to women refugees. What is specific to some women refugees is the way in which the power imbalance manifests itself and whether or not this manifestation will be recognized as persecutory in nature. As Butler (1990) notes, one can question the universality of gender identity and masculinist oppression, both of which assume a shared epistemology and shared structures of oppression, which need not be the case.

While "the personal is the political" is a popular-and often appropriatephrase within western feminist discourse, it is not obvious to me that refugee women themselves would necessarily provide a similar description of their actions, behaviour, or victimization. It is tempting, as Razack (1995) writes, to tell stories in a manner that will appeal to those in a position to make decisions on refugee claims. Such an approach can take on subtle forms, "as when the cultures of refugee women are presented as overly patriarchal."

In sum, it is inaccurate, to say the least, to group women together on the basis of social factors, and it is inappropriate and demeaning to classify them on the grounds of biological factors.

\section{Conclusion}

"Is the construction of the category of Women as a coherent and stable subject an unwitting regulation and reification of gender relations?" asks Butler $(1990,5)$. Does the notion that women refugee claimants form a particular social group maintain a framework that is potentially damaging, or that perpetuates, inadvertently, a power/gender imbalance which endorses the subordination of women refugees within the overriding male refugee definition and experience?

My concern is that by legally defining women as a particular social group, women's powerlessness and marginalization are ensured. It is these very characteristics which allow women refugee claimants to qualify for particular social group status. In a strange way, then, the disempowerment of women is cultivated in order to legitimate, in the eyes of decision makers, their fears - both realized and potential-of persecution.

Men, it must be noted, are not classified as a particular social group. That this is so brings to mind an observation made by Butler $(1990,20)$, who, referring to Wittig (1983), writes that "gender is used in the singular, because indeed there are not two genders. There is only one: the feminine, the 'masculine' not being a gender, for the masculine is not the masculine, but the general." The legitimacy of claiming gender-specific persecution should not rely upon the subordination of women as a whole.

Gender-specific persecution, I believe, should stand alone as a recognized basis for persecution from which some, but luckily not all, women suffer.

\section{References}

Butler, J. 1990. Gender Trouble: Feminism and the Subversion of Identity. London: Routledge.

Castel, J. 1992. "Rape, Sexual Assault and the Meaning of Persecution." International Journal of Refugee Law vol. 4(1): 39-56.

Darton, J. Aug. 9, 1994. "UN Faces Staggering Refugee Crisis." The Globe and Mail. A1, A8.

Goldberg, P. 1993. "Gendered Persecution." Peace Review vol. 5(3): 299-304.

IRB. March, 1993. “Women Refugee Claimants Fearing Gender-Related Persecution." Pursuant to Section 65(3) of the Immigration Act.

Macklin, A. 1993. "Opening the Door to Women Refugees-A First Crack." Paper from the Conference on Gender Issues and Refugees: Development Implications, York University.

_. 1995 (forthcoming). "Opening the Door to Women Refugees-A First Crack." In Gender Development and the Refugee Experience (working title), edited by Wenona Giles, Helene Moussa and Patricia Van Esterik with Victoria Foote. Co-published by Halifax: Fernwood Press and T.B.A.

Mawani, N. 1993. "The Factual and Legal Legitimacy of Addressing Gender Issues." Refuge vol. 13(4): 7-10.

Phelan, S. 1989. Identity Politics: Lesbian Feminism and the Limits of Community. Philidelphia: Temple University Press.

Razack, S. 1995 (forthcoming). "The Perils of Storytelling for Refugee Women." In Gender Development and the Refugee Experience, edited by Wenona Giles, Helene Moussa, and Patricia Van Esterik with Victoria Foote. Co-published by Halifax: Fernwood Press and T.B.A.

Stairs, F. and L. Pope. 1990. "No Place Like Home: Assaulted Migrant Women's Claims to Refugee Status and Landings on Humanitarian and Compassionate Grounds." Journal of Law and Social Policy (6).

UNHCR. 1988. Memorandum No. $77 / 88$ re: Special Canadian Programme for resettlement assistance to refugee women-at-risk, June 23.

UNHCR. 1990. Memorandum re: Amended Guidelines for the Implementation of the Canadian Special Programme for Women-at-Risk, March 12 (AWR). $\square$ 